УДК 811.61.2: 82.1

Ж. В. Колоїз

\title{
СЛОВА МИНУЛОЇ ЕПОХИ В СУЧАСНОМУ ІСТОРИЧНОМУ РОМАНІ ВАСИЛЯ ШКЛЯРА «ЗАЛИШЕНЕЦЬ. ЧОРНИЙ ВОРОН»
}

Колоїз Ж. В. Слова минулої епохи в сучасному історичному романі Василя Шкляра «Залишенець. Чорний Ворон».

У статті з'ясовано семантичні та функціональні особливості застарілої лексики, засвідченої в сучасному історичному романі Василя Шкляра «Залишенець. Чорний Ворон». До аналізу залучено здебільшого військову (батальну) лексику, зокрема одну з найбільш чисельних лексико-семантичних підгруп - «назви військових звань і посад», 3 одного боку, українського повстанського війська, 3 іншого, Червоної армії; окремий акцент зроблено на так званих радянізмах, пов'язаних 3 тогочасним адміністративним і суспільно-політичним життям.

Ключові слова: застаріла лексика, назви військових звань і посад, радянізм, лексико-семантична група.

Колоиз Ж. В. Слова минувшей эпохи в современном историческом романе Василия Шкляра «Залышенец. Черный Ворон».

В статье исследуются стилистические и семантические особенности устаревшей лексики, представленной в современном историческом романе Василия Шкляра «Залышенец. Черный Ворон». Анализируется прежде всего военная (батальная) лексика, одна с наиболее многочисленных лексико-семантических подгрупп - «названия военных званий и посад», с одной стороны, украинского повстанческого войска, с другой, - Красной армии; акцентируется внимание на так называемых советизмах, связанных с административной и общественно-политической жизнью того времени.

Ключевые слова: устаревшая лексика, названия военных званий и посад, советизм, лексико-семантическая группа. 
Kolojiz Zh. V. The words of the past period in modern historical novel of Vasil Shklyar "Zalyshenets. Chornyi Voron".

The article investigates the stylistic and semantic features of obsolete vocabulary presented in the modern historical novel of Vasil Shklyar "Zalyshenets. Chornyi Voron". The military (Battle) vocabulary, one of the most numerous of the lexical-semantic subgroups - "names of military ranks and posts" on the one hand, in the Ukrainian insurgent army, on the other hand - in the Red Army is analyzed. It focuses on Sovietisms related to administrative, social and political life of that time.

Key words: obsolete vocabulary, the names of military ranks and posts, Sovietism, lexical-semantic group.

Постійний і безперервний розвиток лексики, їі кількісні та якісні зміни відбивають мовну еволюцію, спричинену змінами в суспільстві, політичному устрої, духовному і культурному розвитку нації. Функціонування словникового складу мови, як відомо, увесь час супроводжують два основні процеси: поява нових або розширення значень вже наявних слів та відхід на периферію лексичної системи слів, які не задовольняють потреб сучасної комунікації. Вийшовши 3 активного вжитку, слова, які не відповідають «вимогам часу», отримують обмежене функціонування, набувають статусу застарілих, архаїчних. Попри втрачену актуальність вони продовжують використовуються здебільшого ситуативно, принагідно, зокрема для створення колориту зображуваної епохи передусім в історичних творах, де виступають так званими хронологічними маркерами, кваліфікаторами того чи того історичного часу.

Застаріла лексика вже неодноразово ставала предметом зацікавлення як у вітчизняному, так i зарубіжному мовознавстві (В. Ф. Алтайська, О. В. Бабенко, В. Ф. Бєлянська, Л. А. Булаховський, С. І. Буракова, Л. Ю. Бурковська, В. В. Виноградов, Г. М. Гайдученко, Т. В. Гончарова, С. Д. Жорданія, І. А. Забавіна, Г. С. Колесник, О. В. Лєсних, О. Г. Михайлова М. М. Нестеров, М. М. Шанський та ін.). Запропоновані наукові праці переконливо демонструють: серед процесів, які маніфестують особливості розвитку сучасних мов, «пасивізація лексики» (О. А. Стишов) заслуговує на посилену увагу, адже «питання хронологічного маркування лексики пов'язане з безперервним процесом пізнання і відповідною мовною рефлексією на акти пізнання, що одночасно 3 іманентною для мови тенденцією до комунікативної досконалості зумовлює постійний внутрішній рух мови» [9, с. 509].

Традиційно термін «застаріла лексика» використовується як узагальнювальне поняття щодо термінів «архаїзм», «історизм». 
Дослідники запропонували чимало класифікацій застарілої лексики, однак, на жаль, усі вони не є бездоганними. Чіткі межі самих понять «архаїзм», «історизм» так і не окреслені [3; 6]. Натомість у науковому обігу 3'являються і нові терміни «хронізм», «конотативний архаїзм», «агнонім» i т. ін. Очевидно, що проблема хронологічної маркованості слова не є такою простою, як видається на перший погляд. Щоправда, більшість науковців наполягають на тому, що статус «архаїзмів, як і загалом хронологічно маркованої лексики, у системі літературної мови є питанням, що потребує швидше уточнення, ніж кардинального перегляду» [9, с. 508]. Не претендуючи на остаточне розв'язання означеної проблеми, на виокремлення диференційних ознак названих понять i т. ін. [5], ми поставили собі за мету з'ясувати семантичні та функціональні особливості застарілої лексики в сучасному історичному романі Василя Шкляра «Залишенець. Чорний Ворон». Основний акцент зроблено на аналізі лексичних архаїзмів, або історизмів, пов' язаних із тогочасною військовою, адміністративною та суспільно-політичною діяльністю. На нашу увагу заслуговують i одиниці, у яких архаїчним вважається лише певне значення, тобто так звані конотативні архаїзми (О.В.Лєсних).

Історичний роман «Залишенець. Чорний Ворон» Василя Шкляра висвітлює одну 3 найдраматичніших сторінок нашої історії повстанську боротьбу українців проти окупаційної радянської навали. «Дбаючи про правдивість оповіді, письменник відтворює мовну ситуацію в Україні 20-х років минулого століття. Складається вона під впливом збройного наступу російського більшовизму на вже визнану багатьма державами УНР. Чи не вперше так близько і гостро зіткнулися два різні мовно-культурні соціуми на теренах України, де встановлюється радянська влада» [7, с. 374].

Як свідчить опрацьований фактичний матеріал, у мові досліджуваного твору вирізняється три лексико-семантичні групи застарілої лексики: 1) військова (батальна); 2) адміністративна та суспільно-політична; 3) побутова. Остання вже частково ставала предметом нашого зацікавлення [4]. У межах запропонованої праці увагу буде зосереджено в основному на перших двох групах.

Для змалювання реалістичної картини тогочасного життя й оживлення періоду громадянської війни письменник уводить у мову роману слова, які чи то вже давно перебували в пасивному запасі, чи то тільки-но відійшли до лексичного резерву. Наприклад: Та ще чуднішою для нього буде іниа причта на цүій галявині, - цее коли згодом сюди () ж. В. Колоїз, 2012. 
прийдуть іниі люди, вони теліотатимуть нетутешньою мовою, чужі, рогаті, себто в рогатих шапках-будьонівках, незнайомі чорному воронові люди, прийдуть $і$ відміряють двадиять кроків на схід од старезного дуба $i$ стануть копати, і викопають труну, відкриють віко, та замість отамана знайдуть там тільки записку, від якої можнн було здуріти (10, с. 9); Потім ще люди стали шептатися, що козаки поховали Веремія на старому цьвинтарі в ӥхньому-таки селі, поховали серед ночі, так, щуоб навіть жінка $i$ мати не знали, бо рано чи пізно викажуть своїми слізьми могилу отамана (10, с. 23); I потяглися до Кременчука всі оті губревкоми, парткоми, БеБе, губчека, військкоми та всілякі інші «коми», яких наплодила комуна (10, с. 25); За ліпиих часів він би нам знадобився, чорноліський отаман Пилип Хмара таку машпну колись запрягав кіньми й катав дівчат, але то ж Хмара, він навіть випускав власні гроші у своїй окрузі - ходили в його Цвітній та по інших селах тільки такі кредитки Тимчасового уряду, на яких стояла печатка-тризуб і підпис «Хмара» (10, с. 29); Завжденний сум оселився в Чорному Воронові після того, як зустрів $\dddot{̈}-$ - ту, щзо колись присоромила його, бравого офіџера з трьома Георхївськими хрестами на грудях, устидала тяжско й негадано, розбудивии в ньому приспаний гонор (10, с. 31) тощо.

Проілюстровані лексеми (отаман, козак, комуна, губревком, партком, БеБе, губчека, військком і т. ін.) використовуються для позначення осіб, явищ, предметів тощо, інакше кажучи, реалій, пов'язаних із минулим і здебільшого неактуальних для сучасних носіїв мови. Вони маніфестують певний етап мовної картини світу в історії та свідомості народу, є темпорально маркованими: одні з них асоціюються 3 періодом козаччини, інші - стосуються часів дореволюційної Росії (наприклад, Георгіївський хрест - «орден, яким нагороджували в дореволюційній Росії генералів і офіцерів за бойові заслуги та за вислугу років» [2, с. 1572]) та «переможної ходи радянської влади». I ті, і інші належать здебільшого до категорії історизмів, оскільки позначають реалії, що відійшли в небуття. Такі слова у спеціальних лексикографічних працях отримують і спеціальну ремарку (пор.: отаман - «1. icm. Виборний або призначений ватажок козацького війська // Представник козацької адміністрації в населених пунктах в Україні в 17-18 ст. Курінний отаман. Наказний отаман. 2. У дореволюційній Росії начальник козачих військ і поселень, що виконують військові, поліцейські та адміністративні функції. Станичний отаман. 3. У роки громадянської війни - верховода контрреволюційних формувань. 4. заст. Ватажок, керівник // Той, хто очолює, яку-небудь виробничу і т. ін. групу людей. 
5. icm. На Правобережній Україні і в Галичині - сільський староста» [2, с. 865-866]; губревком $\leftarrow$ губком і ревком, де губком - «icm. У СРСР до районування в 1929 р. - губернський комітет РКП(б), потім ВКП(б), ще пізніше - обком ВКП(б) і нарешті обком КПРС» [2, с. 265]; ревком - «icm. 1. Революційний комітет - назва тимчасових надзвичайних органів Радянської влади. 2. розм. Про воєнно-революційні комітети - бойові органи підготовки та проведення збройного повстання, які були створені в Росії в 1917 р.» [2, с. 1205]; партком - «іст. У СРСР: партійний комітет - керівний виборний орган великої первинної організації КПРС» [2, с. 890]; військком - «іст. У Червоній Армії (1918 -1942 рр.) - політичний керівник підрозділу; військовий комісар. 2. Офіцер - начальник військкомату» [2, с. 186]).

Усвідомлюючи те, що 20-ті роки минулого століття - це далеко не період козаччини, доводиться констатувати: ще чимало «білих плям» залишилося не лише в історії України, але й в історії українських слів, зокрема й у їх витлумаченні. Історичний роман репрезентує велику кількість батальної лексики, 3-поміж якої чітко розмежовуються звання та посади військовиків української повстанської армії, з одного боку, та Червоної Армії, що утверджувала «непереможну ходу» радянської влади, - 3 іншого.

Основною, так би мовити, бойовою одиницею українського повстанського війська виступає козак: Коли ми повернулися до Лебединського лісу, я зібрав козаків, прочитав уголос щей папір і передав його шеренгою, щоб кожен міг роздивитися на власні очі $(10$, с. 30$)$; Так само присягаюся вам, щуо особисто я залишатимуся в лісі доти, поки зі мною буде хоч один козак (10, с. 30-31); 3 образливою матючнею та улюлюканням вони заходилися зривати з козаків жовто-блакитні військові відзнаки (10, с. 36); Порозумівиись, вони з потрійною люттю кинулися наздоганяти козаків, які тим часом теж упіймали таву $(10$, с. 54) тощо. Звідси, відповідно, значення слова козак, яке актуалізується в межах проілюстрованих контекстів, можна витлумачити приблизно так: «озброєна людина, яка брала участь у визвольній повстанській боротьбі проти радянської окупаційної влади і вважала себе нащадком запорізьких козаків» (пор.: козак - «1. У 15-18 ст. вільна озброєна людина, що жила на півдні України та брала участь у військових діях проти татаро-турецьких і польських загарбників; нащадок такої людини <...> 2. У дореволюційній Росії 318 ст. - представник військового стану, уродженець військових областей (Кубанської, Оренбурзької, Війська Донського та ін.) // Рядовий кавалерійської частини, 
укомплектованої 3 таких представників. 3. Уродженець колишніх військових областей. 4. Парубок, юнак взагалі // Молодецький ставний парубок. 5. розм. Відважний, завзятий, хоробрий чоловік; молодець. 6. Те саме, що козачок $3 »[2$, с. 551]). До того ж така «бойова одиниця» могла бути не лише особою чоловічої, але й жіночої статі, що підтверджується й відповідними ілюстраціями, як-от: - Так, у загонах часом бувають жінки, але вони сумлінно роблять свою роботу. У Холодному Яру я зустрічав козачку Досю Апілат, то вона вартувала трьох чоловіків (10, с. 188) (пор.: козачка - «дружина або дочка козака» [2, с. 551]). Зауважимо: така лексема здебільшого отримує відповідний атрибутивний конкретизатор - грушівська козачка $(10$, с. 19) (пор.: Запорошена борошном, схожа на поторочу, вона вихопила з-під ряси револьвер. Дося не любила револьверів. Грушківська козачка Дося Апілат любила шаблю. Розгубивиись, вона заточилася і вперлася спиною у двері льоху (10, с. 369).

Лексему козак варто вважати найбільш нейтральною і такою, що виступає синонімічною домінантою в репрезентованому автором синонімічному ряду: козак - гайдамака - повстанець - лісовик партизан. Наприклад: Хто б міг подумати, щзо заломляться такі отамани Холодного Яру, як Деркач, Семен Чучупака (двоюрідний брат Василя), Панченко, а разом із ними ще майже сотня гайдамаків (10, с. 70); Думаю, щуо, якби не чорна безвихідь, мало хто з повстанців заломився б, пішов на амнестію, зрадив ліс (10, с. 50); Їх уже чотири місячі морили в Лук'янівській в'язниці і досі не розстріляли тільки тому, щзо не допиталися прізвищ холодноярських партизанів та підпільників, які залишилися на волі (10, с. 302) тощо. Усі названі лексеми використовуються для означення однієї і тієї ж реалії, можуть виступати як взаємозамінні в межах проілюстрованих контекстів і в тексті роману загалом, хоч вони не є такими в системі мови (наприклад, гайдамака «ісm. 1. Учасник народно-визвольної боротьби 18 ст. на Правобережній Україні проти польсько-шляхетського та єврейського гніту. 2. Під час іноземної інтервенції та громадянської війни 1918-1920 рр. солдат особливих кінних частин Центральної Ради, а також загонів Петлюри та Скоропадського» [2, с. 218] (пор.: Виходити з лісу гайдамакам було не $з$ руки (не їхня то справа - вести фронтальні бої з регулярними частинами), а червоним сунутися до лісу було вкрай небезпечно (10, с. 71). Таке синонімічне розмаїття допомагає авторові уникати тавтології в межах речення та надфразної єдності, як-от: Приймати бій, щүо його нав'язує ворог, та ще й у відкритому полі - не партизанське то діло. Козаки 
нападали знаскоку неждано-негадано, їхньою козирною картою була несподіванка (10, с. 54); Лісовики сходили яром не з боку Мельників (соромно було гайдамакам заходити впокореними до «столиці» Холодного Яру), а ближче сюди до Головківки (10, с. 79) і т. ін. Зрідка з аналогічним значенням використовується й така матеріальна форма вираження, як вояк: Із-за Збруча виступить щуонайменше тридиять тисяч вояків трьома групами: генерал Безручко поведе частину війська на Київ, генерал Удовиченко - на Одесу, Тютюнник на чолі кінноти вирушить між двома арміями на Холодний Яр $i$ зробить його центром загального руху (10, с. 169) (пор.: вояк - «той, хто воює, б'ється з ворогом; боєць, воїн» [2, с. 204]). Аналізований синонімічний ряд увиразнюється також словами, що набувають різних семантичних, стилістичних чи семантикостилістичних відтінків. Наприклад: - Так - то й так, - погодився він. Жаль мені розлучатися з таким козарлюгою, але для початку це тобі буде добра підмога (10, с. 43); До Лебединського лісу - то так, туди йому й лежала дорога, але заразом підкралась охота прогулятися Холодним Яром. Та заодно, може, глянути хоч одним оком на «Мотрю», чи не зібралися там зимувати бурлаки? (10, с. 92); Та ще не встигли сіроми отямитися від такого щастя, як їх уже піджидала смерть (10, с. 116) тощо. Для реалії, означеної звуковим комплексом сірома (пор.: сірома «іст. Козацька біднота на Запорізькій Січі; голота» [2, с. 1325]), використовуються й інші, зокрема сірко, сірий: I ще одну пораду дав Гризло: якщо Чорновус ступив на повстанську стежку, то мусить узяти нове ім'я, інакше москалі помстяться на його родині. Він, Гризло, иъього не зробив, бо на Звенигородщині його знають усі як кошового Вільного козацтва. Кожен сірко вам скаже, хто такий Гризло $і$ з ким він б'ється (10, с. 44); Нам, сірим, зараз було не до того. Ми тільки забрали $з$ машини скриньку гранат «мільса», кулемет «шоша», взяли також ящик доброго вина з печеною поросятиною та паляницею (10, с. 29) (пор.: сірий - «перен. заст. Який належить до непривілейованого класу; простий» [2, с. 1324]). Лексема бурлака отримує авторське витлумачення: «Бурлаками називали гайдамаків, одірваних від родин. Коли на зиму повстанський рух пригасав, багато хто 3 козаків розходилися по домівках, щоб навесні знов повернутися до лісу. А були такі, що залишалися на всю зиму в землянках, - вони не мали куди йти, або остерігалися з' являтися до своїх осель, бо всі вже знали, де вони були до цього» [10, с. 92] (пор.: бурлака - «заст. Людина без постійної роботи і постійного місця проживання» [2, с. 103]). Ті повстанці, для яких ліс став 
постійною домівкою, називалися заприсяжені: Після зимового затишшя повстанський рух прокидався разом із лісом. Оживали бурлаки та місиеві заприсяжені козаки, поверталися ті, хто пересидів зиму по хатах, приходили нові люди (10, с. 111).

У межах історичного роману «Залишенець. Чорний Ворон» представлена ціла низка так званої козацької лексики, використовуваної для номінації тих чи тих представників українського повстанського війська. I це не випадковість. Адже територія, охоплена повстанським рухом, асоціюється з гайдамацьким краєм (Наказ вони мали один - зняти монастирські дзвони. Раз $i$ назавжди знищити головну систему оповімення гайдамацького краю, цієї проклятої Холодноярськоі «республіки», з якою довелося воювати довще і тяжче, ніж із поляками, німиями, Денікіним, Врангелем, Махном (10, с. 82), а сама діяльність повстанців - 3 новітньою Січчю (I під голосіння чернищь вони скинули монастирські дзвони (їх потім також відвезуть до Кременчука, а далі до Харкова, як свідчення перемоги над цією новітньою Січчю, щзо підняла шаблі з-за прадавніх валів), отож вони з великим трудом скинули дзвони, $i$ через те, щуо дуже намучилися, $і$ від жіночих плачів так розлютилися, щуо запалили дзвіницю Івано-Златоустівської цееркви (10, с. 82).

Для означення так званого «верховоди контрреволюційного формування» письменник найчастіше послуговується лексемою отаман: Ворон теж його слухав $і$ дедалі більше переконувався: отаман, котрий дозволяє ворогові вести пропаганду в своєму таборі, заслуговує розстрілу (10, с. 77); Отаман, побачивии, щуо для відступу немає ані шпарини, наказав розсипатися в розстрільну $i$ показати ворогові, на щз здатні козаки (10, с. 146) тощо. Автор зображує ватажка українського повстанського війська в дусі часів Запорізької Січі: У Лисячій балиі, недалечко від Мокроі Калигірки, його перестріли козаки Семена Гризла і привели до отамана перевірити, хто такий. Кремезний, хоч і приземкуватий, Гризло здивував насамперед свойм убранням: синій жупан, розшитий жовтими позументами, шаровари, козащька шапка-бирка, з-під якої над чолом стриміло пасмо русявого чуба. Гострі кінчики вусів були хваџько закручені вгору, щчо надавало обличчю отамана веселого молодецтва (10, с. 38). Підлеглі шанобливо називають його «батьком»: «Добре, батьку!» крикнув йому Чорновус, завертаючи коня у виярок, порослий низькими кущами ожини (10, с. 42); - Чорний Ворон, - сказав він. - Як почуєш, батьку, щось про Чорного Ворона - то буду я (10, с. 44) (пор.: шанобливе звертання солдатів і матросів до старшого офіцера армії та флоту Російської 
імперії: - Так отож. Істинно глаголю вам, ваше високоблагородіє, теє-то будучи, щзо не треба було нам тую машину загранишну палити, оце б зараз, будучи, і підкотили б на ній до клубу, яко проверочна чрезвичайка (10, с. 56).

Так само, як і за часів козаччини, таких очільників було кілька, тому лексема отаман доволі часто отримує матеріальну форму вираження у вигляді множини: Ворон не став розпитувати Досю, де на цю зиму рили землянки (а рили нові неодмінно після того, як заломилися навіть отамани й чимало козаків пішло на амнестію), - не годилося дознаватися про місце зимової оселі тим, хто тут не лишався до весни (10, с. 92); I знову три десятки козаків замаскувалися у грабовому лісі, а троє отаманів руцили до просіки (10, с. 173); Незабаром Завірюха помітив людські постаті, які поволі виринали поміж дерев, вигулькували з чагарників $i$ з ијікавістю дивилися на отаманів, котрі супроводжували до табору, вочевидь, непростого гостя (10, с. 174); Слова словами, але Завірюха перейшов $i$ до діла - кожному отаманові дав иифр під кодовою назвою «Заповіт», шэоб передавати таємну інформацію, вручив також по кілька письмових наказів командувача Чорноморської повстанчої групи, а після того забажав вислухати й самих отаманів (10, с. 175). Кількість отаманів залежала від кількості куренів, кошів і т. ін.: У вересні двадиятого, коли в Мошнах зібралися три курені холоднояриів (уже під проводом Деркача), коли надійшла Степова дивізія Костя Блакитного, підоспіли загони Лютого, Голого, Мамая - нас лише в ијй місцині налічувалося тридиять тисяч, а скільки ж було по всій Украӥні! (10, с. 49) (пор.: курінь - «1. Легка будівля, сторожка. 2. Вбоге житло. 3. icm. Окрема частина Запорізького козацького війська // Одиниця адміністративно-територіального поділу на Січі в межах паланки. 4. icm. Житло козаків, які складали таку частину війська. 5. icm. У період громадянської війни - військова частина контрреволюційного козацтва» [2, с. 598]); Гризло вирішив розділити свій кіш на два загони - $з$ одним Чорновус відійде до Лебедина (10, с. 43) (пор.: кіш - «1. У Київській Русі в 11-13 ст. і в Україні в 14-18 ст. - військовий табір, обоз. 2. Місце перебування запорізьких козаків» [2, с. 543]), а відтак і самі вони кваліфікувалися як курінні, кошові тощо: Колись офічерові ударного батальйону смерті Черноусову навіть уві сні не могло привидітися, щуо він стане курінним 25-го Черкаського куреня $i$, зупиняючи ешелони на станиії Бобринській, ставитиме до муру тих солдатів та офіџерів, з якими пліч-опліч ішов за «царя $i$ отечество» $(10$, с. 35) (пор.: курінний отаман «виборна особа, що керувала куренем; ватажок куреня» [2, с. 598]); Він, Гризло, иъього не зробив, бо на Звенигородщині його знають усі як кошового 
Вільного козащтва (10, с. 44) (пор.: кошовий - «іст. Вождь, отаман на Запорізькій Січі» [2, с. 581]); - Відкіля будеш? - зміряв він Чорновуса очима. - Тільки не крути хвостом, бо моя шабля зразу чує брехню. Чорновусові не було чого кривити душею, $і$ Гризло йому повірив. Та $і$ як не повірити землякові, якщо отаман навіть пригадав його батька знався-бо чи не з усіма лісниками в окрузі. - Приставай до мого коша, - запропонував Гризло (10, с. 38).

3 аналогічним значенням десь-не-день використовується лексема гетьман: Та бракувало нам гетьмана, який придушив би анархію $i$ самоправство (10, с. 48) (пор.: гетьман - «У 16 ст. виборний ватажок козацького війська Запорізької Січі; від 17 ст. до 1764 р. - начальник козацького війська та верховний правитель України» [2, с. 235]).

Задля утвердження вільного духу запорізького козацтва Василь Шкляр активно послуговується й іншими назвами осіб зі статусом застарілих: Коли вони знов зібралися під Гусаковим, Гризло, покликавши окремо стариин, сказав, що в загоні $е$ зрадник (10, с. 96) (пор.: старшина - «4. icm. Офіцерський чин у козацьких військах, що відповідав чинові підполковника, а також особа, що мала цей чин» [2, с. 1386]); $M и$ з сотником Бойком, перечитавщи це повідомлення, лупали очима то один на одного, то знов у газету (10, с. 129) (пор.: сотник - «іст. В Україні в 16-18 ст. - особа, яка очолювала сотню, обиралася спершу козаками, а згодом призначалася гетьманом або царем. 2. Те саме, що сотенний. 3. Особа, яка очолювала сотню в давньоруському війську, а також у стрілецьких військах Московської держави в 16-17 ст. 4. Особа офіцерського чину в козачих військах дореволюційної Росії та кінноті періоду громадянської війни» [2, с. 1359]); - Нема Вовкулаки... - Нема. - Нема нашого бунчужного... Як тепер нам без нього? Він же був... був душею... (10, с. 357) (пор.: бунчужний - «іст. Виборна особа, що мала один з найвищих військових чинів в Україні в 16-18 ст., - охоронник бунчука i командир частини козацького війська» [2, с. 102]); Я ледве не розреготався, спостерігаючи за иією комедією, бо то й справді був мій хорунжий на прізвисько Вовкулака (10, с. 26) (пор.: хорунжий - «іст. 1. Особа, що носила прапор або корогву війська; прапороносець. 2. У 17-18 ст. в Україні особа, що входила до складу генеральної старшини й головним чином інспектувала військо, а також була охоронцем великого полкового і малого прапора» [2, с. 1571]); Всі головні рішення ми ухвалимо на Вищій Отаманській Раді, яка призначається на 28 вересня у м. Звенигородиі. Із-за кордону на 
Раду прибудуть знані українські провідники, зокрема генерал-хорунжсий Гулий-Гуленко та заступник начальника головного повстанчого штабу полковник Ступницький (10, с. 204) (пор.: генерал-хорунжий - «друге за ступенем генеральське звання, а також особа 3 цим званням у військах УНР, Директорії, УПА, польських арміях тощо» [2, с. 230]).

Проілюстровані лексеми можна об'єднати в лексико-семантичну підгрупу «назви військових звань та посад керівної верхівки українського повстанського війська». Вони займають здебільшого проміжну ланку у своєрідній шкалі між крайніми протилежностями козак - отаман, що переконливо демонструють аж ніяк непоодинокі контексти, у яких відповідні компоненти розміщуються чи то по висхідній, чи то по спадній. Наприклад: козак - стариина - отаман (I ніщзо й нікого тепер не обходило, крім цієї пісні, - співали козаки, співали старшини й отамани, до самозабуття віддаючись ичій багатоголосій журбі (10, с. 75); отаман стариина - козак (-Тож я прошу всіх отаманів переказати ие своїм стариинам та козакам і взяти на себе відповідальність за організований саморозпуск. Треба допомогти повстаниям документами, грішии, підсобити тим, хто вийжджатиме в дальші краї (10, с. 142); отаман сотник - козак (Отаман Гонта-Лютий ӥхати до штабу червоних не захотів, послав замість себе сотника Бойка з козаком Чикирдою, а я, пориваючись якомога швидие довести ие діло до кіния, взяв із собою китайця Ходю (10, с. 120). Іноді той чи той ієрархічний компонент може бути матеріально не виражений: Після мене изю фільчину грамоту перечитав сотник Бойко, потім козак Чикирда, і я вже геть здивувався, коли до неї потягся рукою і Ходя (10, с. 126) (пор.: Після отамана изю фільчину грамоту перечитав сотник Бойко, потім козак Чикирда, і я вже геть здивувався, коли до неї потягся рукою і Ходя).

Крім того, у романі представлено ряд лексем, використовуваних для номінації «особи, що перебуває при командирі (штабі) для виконання службових доручень», як-от: Гості нервово виглядали нас на просіиі $і$ вже хотіли їхати геть, аж тут із лісу викотився на гнідій Ларіон Загородній зі своїм ад'ютантом Тимошем Компанійцем і ще одним козаком (10, с. 186) (пор.: ад’ютант - «військовослужбовець (звичайний офіцер), що перебуває при командирі для виконання службових доручень» [2, с. 14]); Ще за тиждень вістовий приніс поголоску: наступної суботи у клубі иукрового заводу збереться чи не вся повітова верхівка, приїде начальство зі Шполи, Звенигородки, Кальниболота, щуоб відгуляти свято врожаю (10, с. 55) (пор.: вістовий - «той, хто виконує доручення командирів штабу; () ж. В. Колоїз, 2012. 
посильний» [2, с. 190]); Тож я вирішив узяти собі за ординарця Ходю $(10$, с. 120) (пор.: ординарець - «військовослужбовець, на якого покладено обов'язки виконувати різні доручення командира або штабу» [2, с. 854]).

Основною бойовою одиницею протилежного військового табору Червоної армії - виступає, цілком закономірно, червоноармієць. Наприклад: Тут, біля дверей, стояло двоє червоноармійців у білих кітелях, вони перевіряли документи, а перед деякими начальниками тільки витягувалися у струну й віддавали «честь» (10, с. 57); За активістами $i$ всякою босотою сиділи в останніх рядах, тримаючи між колін гвинтівки, три десятки червоноармійців, - цих нагнали сюди охороняти поважне зібрання (10, с. 58); Червоноармійці в задніх рядах також загрюкали рушничями об підлогу, заважжаюч одне одному $і$ брязкаючи дулами, бо довгі трилінійки акуратно не вміщалися біля ніг (10, с. 60); Коли вони злізли з коней, до кожного підійшло по двоє червоноармійців - один забирав $i$ відводив убік коня, другий показував на порожній віз, куди треба скидати зброю (10, с. 80); На санях за погонича сидів надутий, як сич, комнезамівець, а по обидва боки йшло, ніби в почесній варті, по двоє червоноармійців (10, с. 108) (пор.: червоноармієць - «іст. Рядовий воїн Червоної армії» [2, с. 1597]) тощо. Проілюстрована лексема має прозору семантику та чітко виражені структурно-граматичні характеристики: спродукована на основі лесичного словосполучення Червона армія внаслідок основоскладання, що супроводжується суфіксацією (пор.: червон+о+армій+ець $\longleftarrow$ Червона армія). Представлена граматичною формою множини, оскільки йдеться не про окремо взятого рядового воїна Червоної армії, а про їх сукупність, де кожен являє собою відповідну бойову одиницю.

Лексема червоноармієць (червоноармійці), будучи синонімічною домінантою, об'єднує навколо себе цілу низку слів 3 аналогічним значенням, що так само пасивізувалися. Заслуговує на увагу передусім субстантивований прикметник червоний (червоні): $A$ наважсився Гальперович покозиритися на американському «пірсі» з відкритим верхом тільки тому, щуо довкола головних доріг кишіли тоді регулярні частини червоних, котрі день у день прибували цілими ешелонами на станцію Бобринську й розповзалися, як мурашва, в напрямку Чигирина, Кам'янки, Черкас, Звенигородки, Знам'янки... (10, с. 25); Чи міг тоді бідолашний Бень передбачити, який «маюфес» влаштують йому червоні головорізи? (10, с. 40); Узяли Черкаси, переповнені червоними з їхніми бронепотягами, мітрельєзами Гочкіса й далекобійними гарматами (з Дніпра навіть 
гатили бронеплави), розтрощили москалів упень, хоча й не одному нашому коневі хвоста відірвало...(10, с. 49); Замість того щзоб тікати чимдуж до лісу, хлопиі повитріщали очі на цю комедію, ждали, поки червоні перетовчуть одне одного, а тоді вже й самим накинутися на те, щуо зостанеться (10, с. 54); Відразу після амністування холоднояриів червоні посунули до Мотриного монастиря - їхня лава тяглася лісовою дорогою від хутора Кресельці аж до плоскогір'я, на якому гніздилась обитель $(10$, c. 80$)$ тощо, де червоні - «іст. Бійці Червоної армії (червоноармійці)» [2, с. 1597]. 3 огляду на те, що Червона армія була створена 23.02.1918 р. для захисту і підтримання Радянської влади, аналізована лексема досить активно використовувалася й для означення всього того, що стосувалося революційної діяльності, пов'язувалося 3 радянським соціалістичним ладом (наприклад, Він так себе розпалив тими червоними святами, щуо вже не витримав, - не чекаючи отаманового сигналу, висмикнув шаблю, махнув раз, другий, хлопиі йому підмогли, й шестеро охоронців зсипного пункту лягли трупом, навіть не писнувши (10, с. 52-53). До того ж відповідна матеріальна форма вираження використовувалася не лише для безпосереднього означення суб'єкта / об'єкта, але й як атрибутивний конкретизатор, наприклад, того чи того підрозділу: Ми знов давали комуні поміж роги - шарпали червоні загони, громили совєтські установи, иукроварні, продовольчі склади, здобуваючи зброю, харчі, одяг, фуражс (10, с. 111); Ніхто не вибігав на вулицю, не метушився, проте з-за кожного тину стирчали вуха і кілька пар очей приглядалося до иієї незвичайної прочесії, щуо гордо прямувала до червоного штабу (10, с. 122); - Командир червоного полку, ще свіжий, тільки позавчора засолив (10, с. 176); Тільки їхати туди було вже запізно - надворі швидко світало, а завидна біля Товмача міг сновигати червоний роз'їз (10, с. 134); Коли вони знов зібралися під Гусаковим, Гризло, покликавии окремо старшин, сказав, щзо в загоні є зрадник. Це він повсякчас наводить на них червоних карателів (10, с. 96); Поки загін Ворона вихопився нагору, червона кавалерія мчала вже за якихось двісті кроків (10, с. 54). Наприклад, червона кавалерія кавалерія червоноармійців $\leftarrow$ кіннота червоноармійців (пор.: кавалерія «кінне військо, кіннота» [2, с. 513]). Подекуди субстантивно-атрибутивні словосполучення 3 відповідним конкретизатором - червоний використовуються й для номінації тих чи тих посад, звань, статусів і т. ін.: Вони скидали на вози зброю, потім під погуки червоних командирів шикувалися лищем до столу, до кумачевого прапора $і$ зніяковілих отаманів, щуо стояли на почесному місиі, низько опустивши голови (10, с. 80); Ми () ж. В. Колоїз, 2012. 
випили, червоні командири знов почали патякати про те, щуо відтепер тільки самогубиі можуть залишатися в лісах, що тих, хто не явиться на амнестію, жде неминуча загибель... (10, с. 130); Після того, як чарупина пройшла по колу, досі мовчазного Голика-Залізняка потягло на балачку, $i$ він, діставши з кишені фотокартку миловидого чоловіка у френчі червоного командира, простяг ї Завірюсі (10, с. 176); I ось тепер, вибираючись на таку важливу й відповідальну зустріч із червоним командуванням, він вирішив зодягнути чей аристократичний балахон 3 бордового атласу (10, с. 122); Наших коней повели до конов'язі, а ми $з$ комісаром Дибенком, комбригом Кузякіним та ще двома червоними начальниками (видно, чекістами) зайили до просторого класу гімназії, облаштованого під їдальню (10, с. 124); Супроводжував нас червоний курсант, мовчазний, трохи розгублений нашим парадним виглядом хохол у рудому кашкеті з надламаним козирком (10, с. 122).

Досить яскравою ілюстрацією синонімічного ряду з синонімічною домінантою червоноармієць (червоноармійці) виступає лексема червінець (червіниі). Значення, актуалізоване в межах досліджуваного тексту, не фіксується спеціальними лексикографічними працями, хоч сама матеріальна форма вираження є кодифікованою (пор.: червінець - «іст. Загальна назва іноземних золотих монет, що були в обігу в допетровській Росії. // Золота монета вартістю три карбованці (у розмовному вжитку також п'ять, десять карбованців), що карбувалися в дореволюційній Росії починаючи 318 ст. 2. icm. Грошовий кредитний білет вартістю десять карбованців, що був в обігу у СРСР з 1922 р. по 1947 р. // icm. розм. Десять карбованців» [2, с. 1597]). Тому, очевидно, задля правильного декодування, слово червінці, яким повстанці називали червоноармійців, береться автором у лапки: А тоді почалося: спериу каральний батальйон наскочив на них у Попівському лісі, насилу відірвалися, потім «червінці» намащали їх $y$ Демуриному, довелося втікати на Мотринські яри (10, с. 96); Шарпали навіть частини регулярного війська, як от, приміром, спільно з отаманом Гонтою-Лютим в одному бою під Звенигородкою витовкли до сотні «червінців» (10, с. 119); Котрийсь із «червінців», глянувии, відвернувся $i$ вистрілив навмання в його бік, та влучив у мертвого Румака (10, с. 136).

Доволі часто в лапки береться ще одна лексема зі статусом застаріла, що знаходиться в межах аналізованого синонімічного ряду, а саме - будьонівець (будьонівці). У буквальному витлумаченні 
означає те саме, що й червоноармієць; пов'язується 3 прізвищем ${ }^{1}$ С. Будьонного, воєначальника СРСР, учасника збройної інтервенції в Україну (1917-1921 рр.) (пор.: будьонівка - «м’який головний убір особливого складу Червоної армії 1919-1941 рр.» [2, с. 100]): Яuа Гальперович звелів водієві зупинитися, аби розпитати в будьонівців, чи не чути тут на дорогах контри (10, с. 26); Сміливці кавполку, побачивии, шуо до хутора втікають будьонівці, а слідом за ними женеться якась банда, 3 криками «ура» рвонули в атаку на переслідувачів (10, с. 54). Узяте в лапки, слово маніфестує невластиве йому значення - «несправжній воїн Червоної армії; перевдягнутий у червоноармійське вбрання повстанець, козак». Наприклад: Один, щуоправда, якось таки прослизнув поміж оглашенними «будьонівцями» й кинув ноги на плечі (10, с. 53); Далі теж усе відбувалося весело, а подекуди й зовсім кумедно. Уже верст через десять наші «будьонівці» наштовхнулися на кінний відділ мілічії, який нишпорив на дорогах спільно $з$ летючим загоном ББ (10, с. 53); Вершники взяли загін Дерези в шільне кільце $і$ тільки тоді, як наблизилися майже впритул, він захвилювався: зночене обмундирування «будьонівців» та їхні неголені щуоки сколихнули в ньому ще неусвідомлену тривогу (10, с. 116). Відповідне значення актуалізується здебільшого не в межах конкретної ситуації, а в межах надфразної єдності, а то й мінімального тексту, де чи то міститься безпосередня вказівка, чи то поєднюються непоєднувані поняття: $A$ все починалося так весело! Невеликим загоном, тридиять п'ять козаків, вони майже парадом зайили в Капітанівку. Всі як один були перевдягнуті в будьонівське манатмя, а Вовкулака ӥхав попереду щуе й червоним прапором (10, с. 52); Денис Гупало, який сховав свого піваршинного оселедця під ганчір'яний будьонівський шолом, навіть

\footnotetext{
1 Тогочасна боротьба основних двох протилежних таборів сприяла появі й інших військових формувань, найменування яких пов'язуються з ім'ям того чи того ідейного провідника. Наприклад: Звенигородку прийили червоні, потім німиі й гетьманці, за ними денікінці, далі петлюрівці, тоді прокотилася кавалерія Периої кінної армї Будьонного, яку перекидали до Криму на Врангелівський фронт із дозволом «самопостачання» дорогою через Україну (10, с. 94) (пор.: денікінець - «іст. Військовик білогвардійської армії генерала Денікіна» [2, с. 284]; петлюрівець - «icm. Учасник петлюрівщини - національно-визвольного руху в Україні періоду іноземної воєнної інтервенції та громадянської війни, очолюваний одним із ватажків партії українських соціал-демократів Симоном Петлюрою» [2, с. 941]); Четверо його синів воювали в Макіӥвського отамана Жуйводи (прозваного так, бо говорив, як воду жував), і троє із них загинули в бою з котовцями на Носачівському полі (10, с. 146), де котовець - «іст. 1. Учасник військових дій під командуванням Г. Косовського, радянського військового та політичного діяча, командира червоноармійських загонів та з'єднань у період громадянської війни (1918-192 рр.). 2. Те саме, що червоноармієць».
} 
почав переконувати Загороднього, що тут щчось нечисте, щчо Завірюха заведе їх під дурного хату, однак Ларіон затявся: розтовкмач мені, щзо тут не так, і тоді я тебе послухаюся (10, с. 205); Момоти сторопіли ще дужче: отакої! - козаки виявилися москалями, а москалі в рогатих будьонівках - козаками. Світ перевернувся догори ногами (10, с. 117) тощо. Остання ситуація засвідчує: по-перше, лексеми козак і москаль, перебуваючи у відношеннях протиставлення, демонструють зразки контекстуальних антонімів, що є поширеними в тексті досліджуваного історичного твору (пор.: Виходити з лісу гайдамакам було не з руки (не їхя то справа - вести фронтальні бої з регулярними частинами), а червоним сунутися до лісу було вкрай небезпечно (10, с. 71); по-друге, аналізований синонімічний ряд із синонімічною домінантою червоноармієць увиразнюється ще однією одиницею - лексемою москаль (пор.: москаль - «заст. Вояк, солдат» [2, с. 691]), яка, як і в першому разі, використовується здебільшого у формі множини. Наприклад: I ще одну пораду дав Гризло: якщз Чорновус ступив на повстанську стежку, то мусить узяти нове ім'я, інакше москалі помстяться на його родині (10, с. 44); Узяли Черкаси, переповнені червоними з їхніми бронепотягами, мітрельєзами Гочкіса ци далекобійними гарматами (з Дніпра навіть гатили бронеплави), розтрощили москалів упень, хоча й не одному нашому коневі хвоста відірвало, потім набрали солі, мила, сірників, тютюну $і$ розійшлися по своїх кутках замість того, щзоб іти далі (10, с. 49); Треба було бачити изю самовдоволену пику з вишкіреними зубами. I як йому пасував червоний прапор! Вовкулака не випускав його з рук навіть тоді, коли шаблею шаткував москалів, щуо охороняли в Капітанівці зсипний пункт (10, с. 52); Із-за иеркви Івана Златоуста вихопилося троє «червінців». Бахнули постріли. Ворон обернувся в бік валу - там теж виросли москалі. Заплутуючись у иинелях, вони бігли до льоху (10, с. 377). Щоправда, на відміну від матеріальної форми вираження на зразок червоноармійці, непоодиноко ілюструє i граматичне значення однини (Чорновус пошкандибав у бік млина, і тут на греблі його перестрів кінний роз'їзд. - Куда, старче, путь дєржіш? - спитав вухатий москаль, такий n'янющий, що однією рукою тримався за повід, а другою вчепився у гриву коня (10, с. 40; Ворон однією рукою звів карабін, $i$ передній москаль зарився носом у землю. Та на валу вже з'явилися вериники (10, с. 377). Задля вираження, власне, негативного ставлення до означених реалій тогочасного буття письменник послуговується й іменником зі збірним 
значенням: Операцію розпочали о четвертій ночі, коли п'яна москальня захропла найміцнішим сном (10, с. 41); Він метався поміж безбожників, хапав їх за руки, за поли, поки хтось не зачідив йому кольбою в обличчя, Варфоломій упав навзнак, і москальня пішла по його мощах потоптом, наступаючи ратицями на голову, груди, живіт, ніби хотіла зрівняти його з землею... (10, с. 82). У деяких ситуаціях лексема може актуалізувати й інше, зокрема розмовне значення, пов' язане з національною належністю; у такому разі йдеться передусім про те, що в лавах Червоної армії перебували люди різних національностей: Москалі казали, щзо Хальоднияр - ие якась древня фортеия ще князя Долгорукого, де всі люди велетенські і довгорукі, чуваші та башкири вважали, щуо Хальоднияр - це ім'я якогось великого полководия, щуось таке, як Чингізхан, котрий так розперезався, щуо не хоче визнавати комуну, китайці сподівалися, щуо ие така закраӥна, обгороджена високим муром, де хоч і холодно, зате повно рису і всілякого їдла, але тим їдлом не хочуть із ними ділитися, а латиші нічого не думали, вони просто були латиськими стрільцями $і$ мовчки ждали наказу (10, с. 25-26) (пор.: латиські стрільці - «військові формування, створені 3 латишів у роки Першої світової війни, які в 1917 році перейшли на бік більшовиків [2, с. 1403]).

Запропонований синонімічний ряд червоноармійці - червоні червінці - будьонівці - москалі доповнюється лексемою більшовики. Наприклад: Вчора в Мокрій Калигіриі більшовики розстріляли сорок наших людей та ще й повісили шістьох жидів, які шили нам одяганку $i$ чоботи (10, с. 38); Той-таки сатана придумав проти нас щуе й «інститут відповідачів» - більшовики розстрілювали селян за зв'язки з лісовиками чи за найменшу підозру в неблагонадійності (10, с. 70); Більшовики швидко зализували рани, їхні каральні загони поповнювалися, наші сили підупадали (10, с. 111) (пор.: білышовик - «іст. Послідовник більшовизму, член більшовицької партії; комуніст» [2, с. 81]). Спродукований на базі аналізованого іменника прикметник більмовицький - слугує атрибутивним поширювачем слова 3 узагальненою семантикою «керівник чого-, кого-небудь», як-от: Коли він стулив на грудях руки долоня до долоні і чемно вклонився, я подумав, що ие навіть завелика честь для більшовицьких командирів - вести до них ось такого тречного воӥна (10, с. 122).

Більш конкретне значення керівної радянської верхівки ілюструє архаїзм комісар (лат. commissare - «посилати 3 місією»), використовуваний для номінації посадової особи, наділеної урядом 
особливими повноваженнями: Так отож після тієї поразки більшовики знов заговорили про амнестію, і сам комісар 145-ї дивізї Дибенко запросив нас до свого штабу в Звенигородку на переговори (10, с. 120). У романі Василя Шкляра засвідчений і розмовний варіант, яким послуговувалися повстанці для номінації відповідної особи жіночої статі, зокрема комісарша: - Гризлові я сказав, щчо брат потрапив у засідку «красних соколят». Ще встиг спровадити на той світ комісаршу, а тоді $і$ його припечатали (10, с. 106). Запозичена лексема комісар згодом отримала відповідник у російськй мові - политрук $\longleftarrow$ политический руководитель, а пізніше і в українській - політрук, політкерівник $\longleftarrow$ політичний керівник (пор.: комісар - «іст. У Червоній армії те саме, що політрук» [2, с. 559]; політрук - «іст. розм. Те саме, що політкерівник; політкерівник - «іст. У Збройних Силах СРСР до 1942 р. особа, яка керувала політичною роботою в підрозділах військових частин» [2, с. 1035]). У перші роки радянської влади чимало $з$ таких осіб були колишніми офіцерами царської армії. Зміну їхніх ідеологічних та політичних уподобань засвідчують спеціальні конкретизатори - більшовицький, червоний і т. ін. Наприклад: Невдовзі всі почули про отамана Веремія. Отаман-вітер. Сьогодні він у Гунському лісі, а взавтра вже на станиії Фундукліївка перевіряє документи в більшовицьких комісарів чи десь під Златополем товче продзагін, який виїхав дерти «развйорстку» (10, с. 46); Тепер він стояв спантеличений, намагаючись угадати, чи перед ним і справді червоний комісар, чи перевдягнутий гайдамака, який прийшов витрясти з нього душу (10, с. 253); - Я ж колись закохалася в галантного штабскапітана, а не в кудлатого гайдамаку. - А червоний комісар тобі не nidxoдить? (10, с. 250). Зауважимо, що колишні офіцери царської армії воювали не лише в рядах Червоної, але й повстанської армії, на чому принагідно акцентує автор. Наприклад, У Ворона (тоді ще не Ворона, а итабс-капітана Черноусова - зробили в армії з Чорновуса) за плечима вже була Омська школа прапорщиків, була війна «за царя і отечество», потім за «душку Керенського», де він сам напросився до ударного батальйону смерті $i$ не раз ходив попідручки з кістлявою свашкою. Першого «георгія» отримав за те, щзо під обстрілом німиів зняв із колючого дроту вже мертвих трьох юнкерів <...> Штабс-капітан Черноусов, відповідаючи на запитання поручника, затинався, немов контужений (10, с. 31), де штабс-капітан - «у дореволюційній російській та деяких іноземних арміях - офіцерський чин у піхоті, артилерії та інженерних військах, рангом вищий поручика i нижчий 
капітана; офіцер у такому чині» [2, с. 1631]; юнкер - «у російській армії та флоті до середини 60-х років 19 ст. - доброволець (рядовий або унтерофіцер) із дворян, який, прослуживши певний термін, міг стати офіцером» [2, с. 1644]; поручник - «заст. розм. Офіцерське звання у царській армії, наступне після чину підпоручика, а також особа, яка мала це звання» [2, с. 1073]).

У тогочасний період лексема комісар послугувала дериваційною базою для похідних, що номінували посади керівної верхівки радянської влади: Він доповість наркому Балицькому, що Мотронинський монастир узято, його дзвони впали до наших ніг (10, с. 86-87), де нарком - «іст. Народний комісар; те саме, що міністр у першому після Жовтневого перевороту уряді» [2, 733] (пор.: комісар $\rightarrow$ народний комісар $\rightarrow$ нарком); Тим часом зірвався зі свого крайнього місия $i$ матусівський воєнком Сємьонов, який вихопив гранату й наган - усі подумали, щчо він зараз влучним пострілом застрелить скажену бабу ягу, але цей навіжений спрямував наган на конвойників, щзо стояли біля лави підсудних (10, с. 289), де воєнком - те саме, що військком (пор.: комісар $\rightarrow$ воєнний (військовий) комісар $\rightarrow$ воєнком (військком). Подібні так звані уламкові абревіатури використовувалися для означення й інших керівних посад, наприклад: Напевно, комбриг Кузякін не знав, що тютюн ще можна вживати $і$ в такий спосіб, ну, може, трохи не такий тютюн, але за воєнного часу перебирати не доводиться (10, с. 128) (пор.: комбриг $\leftarrow$ командир бригади; комбриг - «1. Командуючий бригади. 2. Звання вищого командного складу в Сухопутних військах у Червоній армії 1935-1940 рр.» [2, с. 558]; У них справді була припасена для такого діла ресорна бричка з відкидним верхом, на якій їздив покійний смілянський начміл Косовороткін (10, с. 56) (пор.: начміл $\leftarrow$ начальник мілічіiі) тощо.

Перші роки становлення й утвердження радянської влади, відображені в романі, супроводжувалися виникненням великої кількості нових реалій, які потребували номінації, що й зумовило продукування нових лексем. У цьому плані абревіація виявилася особливо «популярним» способом словотворення, сприяла появі цілої низки так званих радянізмів, пов'язаних із адміністративним та суспільнополітичним життям. Такі тепер уже архаїчні лексеми ілюструють різні типи абревіаціі, як-от: а) позвукову (Сам сатана вигадав неп щзб узяти нас за горлянку. Ми почали втрачати найбільшу опору - селянина, якому нарешті дали дихнути, дозволили погосподарювати, пожити з розв'язаними руками (10, с. 69), де неп 
Ł нова економічна політика, яка, на думку автора, «тимчасово полегшувала становище селянства 3 метою відвернення його від антирадянської боротьби» [10, с. 69] (пор.: неп - «ісm. Нова економічна політика - економічні заходи радянського уряду в 19211929 рр., спрямовані на часткове роздержавлення підприємств для виходу з економічної кризи [2, с. 771]»); б) політерну (Тоді він щуе не знав, щуо через місяцьь відділ ББ вистежить і його останнього сина, $i$ все станеться тут-таки, на їхньому хуторі, станеться ніби зумисне в Онисима на очах, аби він більше не мав до Зінька ні підозр, ні докорів (10, с. 147), де $\boldsymbol{Б \boldsymbol { B }} \leftarrow$ боротьба з бандитизмом; відділ ББ «спецчастина, призначена для боротьби 3 бандитизмом» [10, с. 25]; Особливо заклятим був загін Дерези, сформований з наших таки перевертнів, щуо пішли служити в ЧК (10, с. 115), де $\boldsymbol{\Psi К} \leftarrow$ рос. чрезвичайный комитет); в) уламкову (По дорозі заодно підпалили щуе комнезам, спровадивии його голову до небесної канцелярї̈, й оскільки диму вже було забагато, подалися чимдалі від гріха аж на Старосілля (10, с. 53), де комнезам $\leftarrow$ комітет незаможників (пор.: комнезам - «ісm. Комітет незаможників, організовувався на селі 3 голоти; залучалися до створення комун, колгоспів тощо» [2, с. 560]); Після такого попередження публіка стала на ноги, окрім, певна річ, начальника ревкому Долбоносова, якому вже підвивали чорти (10, с. 61), де ревком ๘ револючійний комітет; - Та щзо, товар веземо в радкоп, - знов пояснив дідок, наче він був тут за стариого $i$ знав більше за всіх. - Нову кооперацію в нас відкрили, а товару катма (10, с. 98), де радкоп Łрадянська кооперація; г) змішану (Сміливці кавполку, побачивши, щуо до хутора втікають будьонівці, а слідом за ними женеться якась банда, з криками «ура» рвонули в атаку на

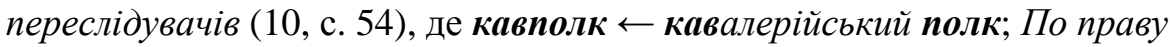
руку від Сєні Качумана сидів діжкуватий начальник упродкому Сиром'ятніков, із пащеки якого тхнуло, як із жомової ями, а лівобіч крутив на всі боки качиною головою начальник ревкому Долбоносов (10, с. 57), де упродком $\leftarrow$ управління продовольчим комітетом); - Пиол вон! - гримнув на нього бородань. - Ти что, не відіш губчека! Щас я лічно проверю, кого ви здєсь собралі! (10, с. 58), де губчека « губернський ЧК) тощо.

Назви адміністративних установ та організацій, проілюстрованих у тексті історичного роману, здебільшого безпосередньо пов'язані з часом становлення радянської влади, тому, очевидно, є соціально-політичними. 
До того ж подекуди зберігаються атрибутивні поширювачі, що маніфестують адміністративно-територіальний устрій дореволюційної Росії, як-от: земство - волость - повіт - губернія. Наприклад: Немає лиха без добра, тож $і$ изього разу так випала карта, щчо доправили його зновтаки аж до Умані, до земської лікарні, де вже лежало чимало наших (10, с. 36); - Та яка там наука, - знизав плечима Ворон. - Після земської школи батечко послав мене аж до Москви на математичні курси (10, с. 106); У Капітанівці вони ще запалили волосний виконком, перед тим забравии в його голови «громадський податок» - сто десять мільйонів совєтських рублів, сто вісімнадиять рублів сріблом та п'ять золотом (10, с. 53); Начальник Звенигородської повітової ЧК Сєня Каџман - симпатичний молодик, тільки сухоребрий $і$ косенький на одне око,- сидячи в першому ряду, теж обливався потом, але не знімав ні кашкета, ні шкірянку, бо, казали, аматорським драматичним гуртком заправляє така кралечка (вона й сама гратиме в п’єсі), щу мусии триматися форсу (10, с. 57); - Славно! А це правда, -обернувся Завірюха до Загороднього, - що ви, пане отамане, недавно заквасили голову повітової чека? (10, с. 177); - Я, будучи, не той денщик, щуо ви собі думаєте, - вів далі навіжений Шельменко. - Я, теє-то, деншик начальника губернської чека $i$, будучи з ним в отсій залі, ще раз наказую всім пред’явить документи (10, с.59). Земство було дуже обмеженим у правах органом місцевого самоврядування, створеним у дореволюційній Росії та Україні відповідно до земельної реформи 1864 р. Основною адміністративно-територіальною одиницею в Росії від початку 18 ст. і в СРСР до районування 1929 р. була губернія, якій підпорядковувалися повіти, що складалися 3 волостей. А відтак назви посад керівної радянської верхівки, проілюстровані в наведених вище контекстах, вибудовуються в ієрархічний ряд: начальник (голова) волосного виконкому $\rightarrow$ начальник (голова) повітової ЧК (чека) $\rightarrow$ начальник (голова) губернської ЧК (чека).

Чимало зі спродукованих внаслідок абревіації радянізмів водночас сприяли появі афіксальних похідних: $K C M \rightarrow$ каесемівець (Тієї ж миті гарячий сільський хлопчина з червоним бантом на лачкані піджака, схожий на каесемівц, а насправді гайдамака Козуб, погрожуючи кольтом, підскочив до охорониів, щуо стерегли вхід, а легкий на ногу Біюж, який до цьього удавав із себе невинне сільське ягня, уже роззброював конвойників, щзо заклякли під прищілом Чорного Ворона (10, с. 289-290) (пор.: Комуністична спілка молоді (перша назва комсомолу) $\rightarrow \boldsymbol{K C M}$; продзагони $\rightarrow$ продзагонівець (Під’йджаючи до просіки, він помітив 
знайомого вершника, зодягнутого, як продзагонівець, $i$ той теж здаля впізнав Гупалового оселедия, бо відразу рушив назустріч (10, с. 173) (пор.: продзагони - «іст. Загони, переважно з робітників, створені в 1917-1920 pр. радянською владою з метою реквізиції хлібних надлишків, охорони продуктових вантажів і т. ін.» [2, с. 1150]); чека $\rightarrow$ чекіст (Але й після того слабенького пуку голова чекіста якось так чудно тріпнулася, $і$ він, уже мертвий, зовсім спокійно відкинувся на спинку сидіння, викликаючи в мене не тільки повагу, а й схвалення (10, с. 27) (пор.: чекіст - «іст. Працівник надзвичайної комісії для боротьби 3 контрреволюцією, саботажем і спекуляцією, яка існувала в перші роки радянської влади» [2, с. 1596]); губчека $\rightarrow$ губчекіст (Троє «губчекістів» тихенько зайшли до зали, а четвертий із коридору шиигнув за лаштунки (10, с. 59) (пор.: губернський чекіст $\rightarrow$ губчекіст); ББ $\rightarrow$ бебех (Хлопець серед ночі навідався додому, $і$ чи його хтось продав, чи «бебехам» самим удалося вистежити, хай там як, але вони оточили хату й будь-щуо хотіли взяти його живим (10, с. 147). Такі архаїзми іноді вводяться до структури апозитивних словосполучень, де один із компонентів подає додаткову характеристику означуваної особи, переважно за родом діяльності: Однак я не про те, я хочу сказати про головного черкаського «бебеха» Яиу Гальперовича, який наважчвся вирушити в таку небезпечну дорогу на авто лише з чотирма чекістами-охоронцями, якщо брати до уваги й шофера (10, с. 25); Та поки що й він мусив спостерігати, як цей чекіст-ахітатор вправляється в красномовстві, вимальовуючи сині далі перед змореними безнадієюлюдьли (10, с. 77$)$ і т. ін.

Примітним є те, що лексема бебех постійно супроводжується лапками: Чого коштувало бодай оте «суворе попередження», яке я знайшов у планшеті головного черкаського «бебеха» Яші Гальперовича, котрий так необачно відважився дістатися на автомобілі аж до Кременчука - непоказного містечка, якому, мабуть, ніколи й не снилося, що воно стане губернським містом, але хай низенько вклониться Холодному Яру та його лісовикам, - ие через них виникла гвалтовна потреба створити новий губернський центр ближче до «осиного гнізда бандитизму» (10, с. 25); Отож головний черкаський «бебех» Яиа Гальперович сміливо, з вітерием $i$ форсом вирушив у відкритому американському «пірсі» на Кременчук, і так не дуже далеко й заїхав, як за Худолївкою вигулькнуло йому назустріч кілька кіннотників у рогатих шапках-будьонівках з величезними ганчір'яними зірками на лобі (10, с. 26) і т. ін. Це, очевидно, слід 
розуміти як своєрідний авторський прийом: 3 одного боку, від абревіатури $\boldsymbol{Б} \boldsymbol{Б}$ утворено похідну одиницю для номінації особи не за допомогою, скажімо, суфікса -icm, як і чекісm, хоч потенційний новотвір на зразок бебіст не суперечив би загальномовним нормам; натомість суфікс - $x$ належить до непродуктивних в українській мові й маніфестується в назвах осіб жіночої статі (дбаха, пряха, сваха); 3 іншого, - авторський новотвір втупає в омонімічні відношення 3 узуальним словом, яке стабілізувалося в мовній системі (бебех «звуконаслідування, що відтворює звук від падіння, удару по чомусь м'якому, пострілу» [2, с. 65]; бебехи - «1. зневажл. Подушки, взагалі пожитки; манатки. 2. Те саме, що нутрощі. 3. розм. Стусани» [2, с. 65]). Такий нібито випадковий збіг забезпечує подвійну актуалізацію та сприяє реалізації відповідного стилістичного ефекту. 3 цією ж самою метою використовується і лексема чопи - «бійці частини особливого призначення» [10, с. 182], що є похідною від абревіатури ЧОП. Наприклад: Ганнуся вже давно його не помічала, Гочмана не було в тому світі, з яким вона прощалася, $i$ це його розлютило ще дужче, - він підвів ї̈ до краю провалля, де зяяла така глибина, що страшно було заглянути, а своӥм «чопам» наказав спішитися і стати «в ружйо!» (10, с. 182); «Чопи» рипнулися було опинатися, проте Гоцман, тверезий від холодного дотику дула, подав їм знак підкоритися (10, с. 183) (пор.: чіп - «конусоподібна дерев’яна пробка для закупорювання отвору в якій-небудь посудині (переважно в бочці)» [2, с. 1603]). Щоправда, уже інше похідне - чопівець - не супроводжується лапками: Вони чекали нового нападу чопівців, як раптом постріли, що глухо розлягалися по той бік ліска, стали лункішими (10, с. 234). Доволі часто лапки використовуються й тоді, коли автор репрезентує лексеми, породжені не лише новими тогочасними реаліями, але й чужою культурою, чужомовним середовищем: Це вони виконали місячний план заготівлі хліба, здерши серпневу «развйорстку» (10, с. 55) (пор.: розверстка - «іст. У період «воєнного комунізму» - спосіб державної заготівлі сільськогосподарських продуктів, який полягав у тому, що селяни повинні були здавати всі надлишки продукти від норм, установлених на особисті потреби» [2, с. 1234]); Вовкулака зовсім розгубився, адже мав іншу серйозну роботу, вони з Ходею і Біжу вже третій день иукали слідів «дайошів», та ще нічого не прочули за чужиния з червоною плямою на півщоки...(10, с. 184) (пор.: дайоші - «кримінальні бандити 3 () Ж. В. Колоїз, 2012. 
дезертирів Червоної армії, які часто маскувалися під повстанців; від російського слова-гасла «дайош!» [10, с. 156]). Пор. також: Чихвостили продзагони, чрезвичайку, мілічію, чопівців, трусили червоні установи, колошматили всіляких активістів, котрі боялися нашого духу, десятою дорогою обминали ліси, добачаючи месника в кожному дереві й кущику (10, с. 164); проілюстроване слово чрезвичайка утворено внаслідок універбізації на основі того ж російськомовного словосполучення, що послужило дериваційною базою й для абревіатури ЧК.

Мова сучасного історичного роману репрезентує й інші тепер уже архаїчні лексеми, спродуковані свого часу не лише за допомогою морфологічних способів словотворення. До розряду конотативних архаїзмів можна зарахувати оказіональне утворення мухомор (мухомори), що виникло внаслідок переосмислення семантики: Поранило його серед ночі: спершу вони з Ларіоном Загороднім наскочили на червону залогу в селі Федвар, - дізналися, щуо окупанти роздали зброю місчевим мухоморам, аби ті боролися з бандитами, таких «сміливців» виявилося зо три десятки, $i$ вони, пришелепки, серед білого дня відкрили по лісовиках безладну стрілянину, тож довелося надавати чортів, забрати на тачанки їхню дармову зброю... (10, с. 172). Така матеріальна форма вираження використовувалася для означення особи (осіб), зокрема тих місцевих мешканців, які під загрозою смерті або з корисливих мотивів переходили на бік червоних [10, с. 172] (пор.: узуальне слово мухомор - «отруйний гриб на високій тонкій ніжці, з великою червоною шапкою, вкритою білими цятками» [2, с. 697]).

Проведений аналіз застарілої лексики, засвідченої в мові популярного нині історичного роману, не є всебічним і не обмежується лише згадуваними одиницями. Крім маніфестованих лексико-семантичних груп (військова (батальна) лексика (підгрупа «назви військових звань і посад); адміністративна лексика; суспільно-політична лексика), заслуговує на увагу військова лексика на означення зброї та так звана побутова лексика. У романі представлено цікавий матеріал, що ілюструє стилістичні особливості власне лексичних, лексико-семантичних, лексикословотвірних, лексико-морфологічних, лексико-фонетичних архаїзмів.Усі вони, як і залучені до аналізу лексичні одиниці, слугують для довершеного змалювання правдивої картини тогочасного суспільно-політичного та адміністративного життя. Архаїчні лексеми $є$ елементом стилізації історичної епохи і в такому ракурсі розширюють реєстр прийомів 
художнього стилю, а отже і його функціональні можливості; засобом історичної конкретизації - аспект ідентифікації, комунікативної достовірності, точності; прийомом персоніфікації, ідіолістичної маркованості персонажів; засобом художнього моделювання текстових конотацій для досягнення комічного, сатиричного ефекту та створення патетики [9, с. 511]. Архаїчна лексика використовується не лише для відтворення історичного колориту, але й загалом відіграє важливу роль у комунікативній взаємодії різних поколінь.

Узагальнюючи сказане, зауважимо: використання застарілих слів у мові історичного роману визначається принципом історизму, дотриманням художнього хронотопу та художньої стилізації, що дало змогу авторові, не створюючи відчуття архаїчності мови твору, об' єктивно репрезентувати зображувані події, наблизити читача й допомогти зрозуміти загальний характер минулої радянської епохи, повніше розкрити образи вигаданих і «реставрувати» маловідомі реальні постаті, події і т. ін., установити справедливість, ліквідувати «білі плями» в історії України 20-х рр. ХХ ст.

\section{Література}

1. Бурківська Л. Ю. Лексика історичної прози Богдана Лепкого в контексті загальнолітературної та стилістичної норми : автореф. дис. ... канд. філол. наук : спец. 10.02 .01 «Українська мова» / Л. Ю. Бурківська. - К., 2003. - 23 с.

2. Великий тлумачний словник сучасної української мови / упорядн. та гол. ред. : В. Т. Бусел. - К. - Ірпінь : Перун, 2009. - 1736 с.

3. Гайдученко Г. М. Стилістичний потенціал хронологічно маркованої лексики в українських історичних романах / Г. М. Гайдученко // Українська мова вчора, сьогодні, завтра в Україні і світі : [зб. наук. праць]; За ред. П. П. Кононенко. - К. : Міленіум, 2006. [Електронний ресурс] - Режим доступу : http://www.kspu.edu/FileDownload.ashx?id=257652993ec1-449f-ab59-ee2545c1656f

4. Колоїз Ж. В. Лексико-семантична група «назви одягу» в романі Василя Шкляра «Залишенець. Чорний Ворон» / Ж. В. Колоїз // Філологічні студії : Науковий вісник Криворізького державного педагогічного університету : [зб. наук. праць]. - Вип. 6. - Ч. $2 /$ ред. : Ж. В. Колоїз (відп. ред.), П. І. Білоусенко, В. П. Олексенко та ін. - Кривий Ріг : КДПУ, 2011. - С.175-197.

5. Колоїз Ж. В. Лексичні архаїзми у творчій спадщині Івана Нечуя-Левицького / Ж. В. Колоїз // Філологічні студії : Науковий вісник Криворізького державного педагогічного університету : [зб. наук. праць]. - Вип. 3 / ред. : Ж. В. Колоїз (відп. ред.), П. І. Білоусенко, В. П. Олексенко та ін. - Кривий Ріг : Видавничий дім, 2009. - С. 64-77.

6. Лесных Е. В. Архаизация лексики русского языка XX века : автореферат дис.... канд. филол. наук : спец. 10.02.01 «Русский язык» / Е. В. Лесных. - Елец, 2002. [Електронный ресурс] - Режим доступа : http://dissertation2.narod.ru/avtoreferats7/aa7.htm

7. Семиряк В. Д. Русизми й українізми в контексті роману Василя Шкляра «Залишенець. Чорний Ворон» / В. Д. Семиряк // Вісник ЗНУ : Серія : Філологічні науки. - 2012. - №1. - С. 374-376.

() ж. В. Колоїз, 2012. 
8. Стишов О. А. Українська лексика кінця XX століття (на матеріалі мови засобів масової інформації) : [монографія] / О. А. Стишов. - К. : Вид. центр КНЛУ, 2003. - 388 c.

9. Шевченко Л. І. Архаїзми в дискурсі проблем функціонального розвитку мови / Л. І. Шевченко // Дискурс сучасної історичної романістики : поетика жанру : [зб. наук. праць]. - К., 2000.- С. 508-513.

10.Шкляр В. М. Залишенець. Чорний Ворон : [текст] / В. М. Шкляр. - Харків : «Клуб сімейного дозвілля», 2011. - 384 с.

Стаття надійшла до редакції 12.09.2012 p. 